\title{
Chemotherapeutic and Safety Profile of a Fraction from Mimosa caesalpiniifolia Stem Bark
}

\author{
Paulo Michel Pinheiro Ferreira $\mathbb{D D}^{1,2}$ Renata Rosado Drumond ${ }^{10},{ }^{1,2}$ \\ Jurandy do Nascimento Silva $\mathbb{D}^{1,2}$ Ian Jhemes Oliveira Sousa $\mathbb{D},^{1}$ \\ Marcus Vinicius Oliveira Barros de Alencar $\mathbb{D}^{2,3}$ Ana Maria Oliveira Ferreira da Mata $\mathbb{D}^{2,3}$ \\ Nayana Bruna Nery Monção (iD), Antonia Maria das Graças Lopes Citó (iD, ${ }^{4}$ \\ Ana Fontenele Urano Carvalho $\mathbb{D}^{5},{ }^{5}$ Davi Felipe Farias $\mathbb{D}^{\mathrm{D}},{ }^{6}$ Patrícia Marçal da Costa $(\mathbb{D})^{7}$ \\ Adriana Maria Viana Nunes $\mathbb{D}^{1},{ }^{1}$ João Marcelo de Castro e Sousa $\mathbb{D D}^{2,3}$ \\ and Ana Amélia de Carvalho Melo-Cavalcante $\mathbb{D}^{2,3}$
}

\footnotetext{
${ }^{1}$ Laboratory of Experimental Cancerology (LabCancer), Department of Biophysics and Physiology, Federal University of Piauí, Teresina, Brazil

${ }^{2}$ Postgraduate Program in Pharmaceutical Sciences, Federal University of Piauí, Teresina, Brazil

${ }^{3}$ Laboratory of Genetic Toxicology (Lapgenic), Department of Biochemistry and Pharmacology, Federal University of Piauí, Teresina, Brazil

${ }^{4}$ Department of Chemistry, Federal University of Piauí, Teresina, Brazil

${ }^{5}$ Department of Biology, Federal University of Ceará, Fortaleza, Brazil

${ }^{6}$ Department of Molecular Biology, Federal University of Paraíba, João Pessoa, Brazil

${ }^{7}$ Faculty of Medicine, State University of Ceará, Fortaleza, Brazil
}

Correspondence should be addressed to Paulo Michel Pinheiro Ferreira; pmpf@ufpi.edu.br

Received 23 July 2021; Revised 22 October 2021; Accepted 17 November 2021; Published 7 December 2021

Academic Editor: Liren Qian

Copyright (c) 2021 Paulo Michel Pinheiro Ferreira et al. This is an open access article distributed under the Creative Commons Attribution License, which permits unrestricted use, distribution, and reproduction in any medium, provided the original work is properly cited.

\footnotetext{
Mimosa caesalpiniifolia (Fabaceae) is used by Brazilian people to treat hypertension, bronchitis, and skin infections. Herein, we evaluated the antiproliferative action of the dichloromethane fraction from M. caesalpiniifolia (DFMC) stem bark on murine tumor cells and the in vivo toxicogenetic profile. Initially, the cytotoxic activity of DFMC on primary cultures of Sarcoma 180 (S180) cells by Alamar Blue, trypan, and cytokinesis block micronucleus (CBMN) assays was assessed after $72 \mathrm{~h}$ of exposure, followed by the treatment of S180-bearing Swiss mice for 7 days, physiological investigations, and DNA/chromosomal damage. DFMC and betulinic acid revealed similar in vitro antiproliferative action on S180 cells and induced a reduction in viable cells, induced a reduction in viable cells and caused the emergence of bridges, buds, and morphological features of apoptosis and necrosis. S180-transplanted mice treated with DFMC (50 and $100 \mathrm{mg} / \mathrm{kg} /$ day), a betulinic acid-rich dichloromethane, showed for the first time in vivo tumor growth reduction (64.8 and 80.0\%) and poorer peri- and intratumor quantities of vessels. Such antiproliferative action was associated with detectible side effects (loss of weight, reduction of spleen, lymphocytopenia, and neutrophilia and increasing of GOT and micronucleus in bone marrow), but preclinical general anticancer properties of the DFMC were not threatened by toxicological effects, and these biomedical discoveries validate the ethnopharmacological reputation of Mimosa species as emerging phytotherapy sources of lead molecules.
} 


\section{Introduction}

The history of anticancer drugs is closely related to natural products, since at least $60 \%$ of clinical drugs naturally or chemically resemble ones [1]. In this context, Brazil remains at the top of 17 megadiverse countries and the home of around $20 \%$ of the world species [2], mainly because approximately 700 new animal species have been discovered each year [3]; it has the greatest number of endemic species on a global scale and about 55,000 plant species $(22 \%$ of the world total) $[4,5]$. Moreover, it is a great producer of medicinal plants for internal consumption as well as for international markets. This invaluable biodiversity encourages biotechnological and pharmacological studies about effective therapy and health recovery [6-8].

A Brazilian dry region named "Caatinga" dominates 7\% of the Brazilian territory and is an exclusive biome. It generates particular environmental conditions for steppe climate-adapted flora and fauna and a high number of rare and endemic taxa $[9,10]$, exhibiting many vegetal families, such as Fabaceae, Anarcadiaceae, Caryocaraceae, Rhamnaceae, Chrysobalanaceae, Clusiaceae, Connaraceae, Sapindaceae, Annonaceae, Combretaceae, and Bignoniaceae [11-15]. Among them, inflorescences from Mimosa caesalpiniifolia Benth. (synonym: Mimosa caesalpiniaefolia, family Fabaceae), known as "unha de gato," "sabiá," and sansão-do-campo," have been traditionally used by Brazilian people as hedges and windbreaks. Dried fruits and leaves are given as fodder for cattle, goats, and sheep (crude protein ranging from 13.4 to $17.1 \%$ ) [16] and to treat hypertension [17]. Its bark is popularly used as a coagulant to stop or avoid bleeding and as wound washing to prevent inflammation and skin infections. Moreover, the ingestion of bark infusion alleviates symptoms of bronchitis $[16,18,19]$. Recently, a bioassay-guided phytochemical study found 28 compounds in $M$. caesalpiniifolia leaf extract, and four of them revealed potent antifungal properties against Candida glabrata and Candida krusei [20]; the latter was often associated with the prior use of azoles and corticosteroids, bone marrow transplantation, malignant hematological diseases, and neutropenia [21].

An expert Brazilian research group about pharmacology of natural products confirmed bioactivity usages for cardiovascular diseases. They reported that ethanolic extracts of different parts of M. caesalpiniifolia (leaves, bark, fruit, and inflorescences) cause vasorelaxation, the tea of flowers promotes hypotension and tachycardia, and the ethanolic extract causes hypotension and bradycardia [22]. Based on these ethnopharmacological properties, this work evaluated the antiproliferative action of the dichloromethane fraction from M. caesalpiniifolia (DFMC) stem bark on murine tumor cells and the in vivo toxicogenetic profile.

\section{Materials and Methods}

2.1. Plant Collection and Extract/Fraction Preparation. Plant specimens were collected in May 2010 in Teresina (Piauí, Brazil). A voucher sample (26.824) was deposited at Graziela Barroso Herbarium at Federal University of Piauí
(Teresina, Piauí, Brazil). Air-dried plant material was pulverized, extracted with ethanol, concentrated under reduced pressure, and subjected to successive partitioning with dichloromethane as described by Silva et al. [15]. Previously, we isolated betulinic acid [3 $\beta$-hydroxy-lup-20(29)-en-28-oic acid] and verified it as the main compound in the dichloromethane fraction $(\sim 70.3 \%)$, as demonstrated by TLC (thin-layer chromatography), GC-qMS (gas chromatograph quadrupole mass spectrometer), HRAPCIMS (high-resolution atmospheric pressure chemical ionization mass spectrometer), ${ }^{1} \mathrm{H}$ - and ${ }^{13} \mathrm{C}$-nuclear magnetic resonance, and DEPT analysis $[15,23]$. Plant samplings were authorized by the System of Authorization and Information on Biodiversity (SISBIO/BAMA \#50090-3) and registered in SisGen (Sistema Nacional de Gestão do Patrimônio Genético $e$ do Conhecimento Tradicional Associado \#ABC4AC2) according to Brazilian legislation (Federal Law No 13,123/ 2015). These investigations were performed using the fraction composed of a mixture of molecules because such preparations represent the main folk approach of consumption by the Brazilian population [15].

2.2. Animal's Facilities. Adult female Swiss mice (Mus musculus Linnaeus, 1758) weighing 20-25g were obtained from the animal facilities at Universidade Federal do Piauí (UFPI), Teresina, Brazil. All animals were maintained in well-ventilated cages under standard conditions of light (12 h with alternate day and night cycles) and temperature $\left(25 \pm 2^{\circ} \mathrm{C}\right)$ with free access to food (Nutrilabor ${ }^{\mathrm{TM}}$, Campinas, Brazil) and drinkable water. After the tests, mice were euthanized with sodium thiopental $(100 \mathrm{mg} / \mathrm{kg})$ (i.p.). All protocols were approved by the Ethical Committee on Animal Experimentation at UFPI (CEUA \#034/2014) and followed Brazilian (Sociedade Brasileira de Ciência em Animais de Laboratório-SBCAL) and international (Directive 2010/63/EU of the European Parliament and of the Council on the protection of animals used for scientific purposes) rules on the care and use of experimental animals.

\subsection{In vitro Antiproliferative Studies on Sarcoma 180 Cells}

2.3.1. Ex vivo Cytotoxic Action. Mice with 9 to 10 days of S180 ascitic tumors were euthanized with an overdose of sodium thiopental, and a suspension of S180 cells was taken from the intraperitoneal cavity under aseptic conditions. The cell suspension was centrifuged at $2,000 \mathrm{rpm}$ for $5 \mathrm{~min}$ to obtain a pellet, which was washed three times with sterile RPMI medium. The cell concentration was adjusted to $0.5 \times 10^{6}$ cells $/ \mathrm{mL}$ in RPMI-1640 medium supplemented with $20 \%$ fetal bovine serum, $2 \mathrm{mM}$ glutamine, $100 \mathrm{U} / \mathrm{mL}$ penicillin, and $100 \mu \mathrm{g} / \mathrm{mL}$ streptomycin (Cultilab ${ }^{\mathrm{TM}}$, Brazil), plated in 96-well plates with increasing concentrations $(0.8-50 \mu \mathrm{g} / \mathrm{mL})$ of DFMC and betulinic acid, and incubated at $37^{\circ} \mathrm{C}$ in a $5 \% \mathrm{CO}_{2}$ atmosphere (Shel Lab $\mathrm{CO}_{2}$ Incubator, USA).

Cell proliferation was assessed by the Alamar Blue ${ }^{\mathrm{TM}}$ assay after $72 \mathrm{~h}$. At $48 \mathrm{~h}$ of incubation, $20 \mu \mathrm{L}$ of stock solution $(0.156 \mathrm{mg} / \mathrm{mL})$ of Alamar Blue ${ }^{\mathrm{TM}}$ (Resazurin, Sigma 
Aldrich $^{\mathrm{TM}}$, USA) was added to each well. Cell proliferation was determined spectrophotometrically using a multiplate reader (T80+ UV/VIS Spectrometer, PG Instruments ${ }^{\mathrm{TM}}$, United Kingdom) at 570 and $595 \mathrm{~nm}$. The antiproliferative effect was expressed as the percentage of the control according to Ferreira et al. [12].

2.3.2. Trypan Blue Exclusion Assay. Sarcoma 180 cells $\left(0.5 \times 10^{6} \mathrm{cells} / \mathrm{mL}\right)$ plated in 24 -well plates were exposed to DFMC at 5, 10, and $25 \mu \mathrm{g} / \mathrm{mL}$. Doxorubicin (Dox, $0.3 \mu \mathrm{g} /$ $\mathrm{mL}$ ) was used as a positive control. Cell viability was examined by the exclusion of trypan blue [24]. Briefly, aliquots of $10 \mu \mathrm{L}$ were collected from DFMC-treated S180 cultures after $72 \mathrm{~h}$ of exposure, and viability was separated into viable blue-marked and nonviable blue-coloured cells in a Neubauer chamber under light microscopy (Biosystems ${ }^{\mathrm{TM}}$, USA).

2.3.3. Cytokinesis-Block Micronucleus (CBMN) Assay. Sarcoma 180 cells were plated in 24-well plates $\left(0.5 \times 10^{6}\right.$ cells $\left./ \mathrm{mL}\right)$ and treated with DFMC at 5, 25, and $50 \mu \mathrm{g} / \mathrm{mL}$. After $44 \mathrm{~h}$ at $37^{\circ} \mathrm{C}$, cytochalasin B (Sigma Aldrich, USA, $6 \mu \mathrm{g} / \mathrm{mL}$ ) was added, and the cells were reincubated for an additional $28 \mathrm{~h}$. At $72 \mathrm{~h}$, the cultures were transferred to tubes and centrifuged at $800 \mathrm{rpm}$ for 5 minutes. Then, the supernatant was removed, and the body of the cell bottom was enlarged and centrifuged again before the addition of $2 \mathrm{~mL}$ of fixing solution (methanol and acetic acid, ratio $5: 1$ ) and 3 drops of formaldehyde $37 \%$ (Vetec $^{\mathrm{TM}}$, Brazil). This procedure was repeated $3 x$ using fixing solution $3: 1$ without formaldehyde. Supernatants were discarded, and 2-3 drops of cell suspension were dripped onto slides and stained with Giemsa for $5 \mathrm{~min}$ [25]. Considering blind examination, a total of 2000 cells by concentration were counted by optical microscopy at 1000x (1000 cells/slide) to count buds, bridges, and micronuclei.

\subsection{In vivo Assays}

2.4.1. Assessment of Antitumor Capacity, Physiological Parameters, and Histological Aspects. Ten-day-old S180 ascites tumor cells were removed from the peritoneal cavity, counted $\left(6 \times 10^{6}\right.$ cells $\left./ \mathrm{mL}\right)$ and subcutaneously implanted into the right hind axillary of healthy Swiss animals. On the next day, they were randomly divided into four groups $(n=10$ each). DFMC dissolved in dimethylsulfoxide (DMSO $5 \%$, Vetec ${ }^{\mathrm{TM}}$, Brazil) was intraperitoneally injected at 50 or $100 \mathrm{mg} / \mathrm{kg} /$ day for 7 days. Negative and positive controls received DMSO 5\% and 5-fluoruracil (5-FU, $25 \mathrm{mg} / \mathrm{kg} / \mathrm{day}$, Sigma Aldrich ${ }^{\mathrm{TM}}$, USA), respectively [26].

All animals were anaesthetized on day 8 with ketamine $(90 \mathrm{mg} / \mathrm{kg})$-xylazine $(4.5 \mathrm{mg} / \mathrm{kg})$ for cardiac puncture blood collection [27] using sterile tubes and heparinize pipettes to determine hematological parameters (erythrocytes, leukocytes, platelets, hemoglobin, and hematocrit) in peripheral blood samples using an automatic analyzer of hematologic cells (SDH-3 Vet Labtest ${ }^{\mathrm{TM}}$, Brazil). The absolute count of white cellular subtypes was calculated as the product of its respective differential percentage and total leukocyte count. For biochemical analysis, blood samples were centrifuged at 2,000 rpm for 5 minutes. Physiological markers of the liver [blood urea nitrogen (BUN), glutamate oxaloacetate transaminase (GOT), glutamate pyruvate transaminase (GPT), alkaline phosphatase (ALP)] and kidneys (creatinine) were evaluated according to Labmax Plenno Labtest ${ }^{\mathrm{TM}}$. Subsequently, all animals were euthanized to dissect out the liver, kidneys, spleen, stomach, heart, and lungs to estimate wet relative weights and for macroscopic analysis. Next, organs were fixed with $10 \%$ buffered formalin, processed, and cut into small pieces to prepare histological sections (4-7 $\mu \mathrm{m})$. Staining was carried out with hematoxylin and eosin (H\&E, Vetec ${ }^{\mathrm{TM}}$, Brazil). Morphological blind analyses were performed under light microscopy (Olympus ${ }^{\mathrm{TM}}$, Japan) by an expert pathologist.

2.4.2. Determination of Chromosomal Damages. The femurs were removed and carefully cleaned, and proximal epiphyses were sectioned. Bone marrow samples were collected using $5 \mathrm{~mL}$ syringes filled with $0.5 \mathrm{~mL}$ of sterile fetal bovine serum (Cultilab ${ }^{\mathrm{TM}}$, Brazil), centrifuged, and homogenized. Drops of cell suspension were transferred to slides to prepare smears (two slides/animal), fixed and stained by the Leishman method. All analyses were blindly performed under light microscopy (Olympus ${ }^{\mathrm{TM}}$, Japan) with magnifications of 200x and 400x. We considered micronuclei to be rounded structures, with a diameter of $1 / 5$ to $1 / 20$ found in young erythrocytes and identified by bluish staining. A total of 1,000 polychromatic erythrocytes (PCEs) was quantified per slide (two slides/animal) [28-30].

2.5. Statistical Analysis. Half maximal inhibitory concentration $\left(\mathrm{IC}_{50}\right)$ and their $95 \%$ confidence intervals were calculated by nonlinear regression (GraphPad Prisma 9.0, Intuitive Software for Science, USA). Statistical differences were evaluated comparing data [mean \pm standard error of mean (S.E.M.)] by one-way analysis of variance (ANOVA) and Newman-Keuls test as post hoc test $(p<0.05)$. All in vitro studies were carried out in duplicate $(n=3 /$ concentration) and represent independent biological evaluations.

\section{Results}

3.1. In vitro Antiproliferative Action on Sarcoma 180 Cells: Cytotoxicity, Chromosomal Changes, and Cell Death Pattern. DFMC and betulinic acid revealed similar in vitro antiproliferative activity against $S 180$ cells after $72 \mathrm{~h}$ of incubation, with $\mathrm{IC}_{50}$ values of $29.0(24.9-33.6) \mu \mathrm{g} / \mathrm{mL}$ and 33.7 $(30.1-37.6) \mu \mathrm{g} / \mathrm{mL}$, respectively ( $p>0.05$, Table 1). Afterwards, this action was confirmed by trypan blue assay (Figure 1), a direct method to detect cytotoxicity, which showed that all concentrations of DFMC $(5,25$, and $50 \mu \mathrm{g} / \mathrm{mL})$ reduced the number of viable cells $(48.2 \pm 7.1$, $87.6 \pm 1.4$, and $98.7 \pm 0.5 \%$, respectively) when compared to the negative control $(p<0.05)$.

Morphological analysis of DFMC-treated Sarcoma 180 cells did not show significant micronucleus induction 
TABLE 1: Cytotoxic activity of the dichloromethane fraction and betulinic acid from Mimosa caesalpiniifolia (DFMC) stem bark on primary culture of sarcoma 180 cells after $72 \mathrm{~h}$ of exposure evaluated by alamar blue assay.

\begin{tabular}{lcr}
\hline Sample & \multicolumn{1}{c}{$\mathrm{IC}_{50}(\mu \mathrm{g} / \mathrm{mL})$} & $R^{2}$ \\
\hline DFMC & Sarcoma 180 cells & 0.9278 \\
Betulinic acid & $29.0(24.9-33.6)$ & 0.9292 \\
Doxorubicin & $33.7(30.1-37.6)$ & 0.9801 \\
\hline
\end{tabular}

Data are presented as $\mathrm{IC}_{50}$ values and $95 \%$ confidence intervals. Doxorubicin was used as positive control. Experiments were performed in duplicate.

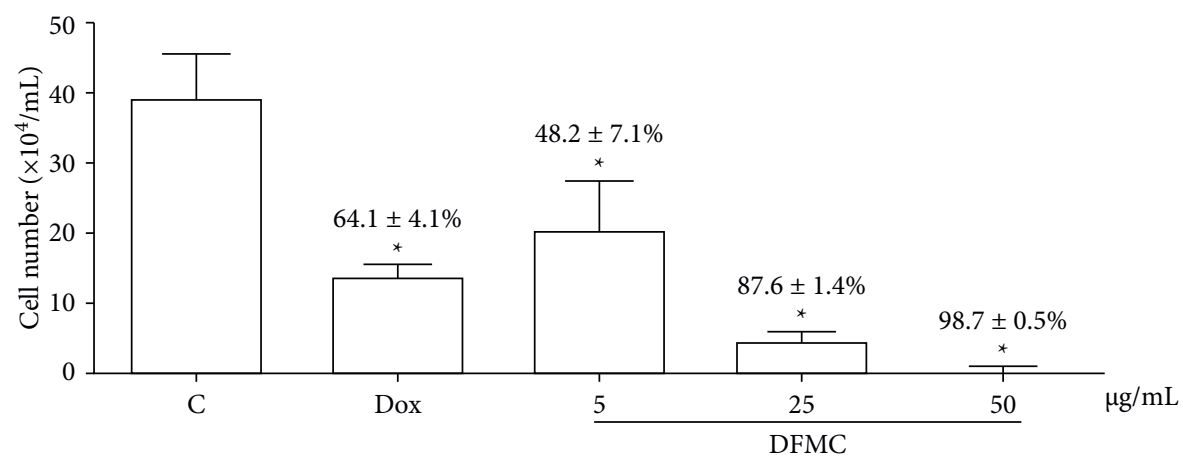

FiguRE 1: The cell number of viable cells was determined by trypan blue staining and analyzed by light microscopy after $72 \mathrm{~h}$ of exposure to the dichloromethane fraction from Mimosa caesalpiniifolia (DFMC) stem bark. The percentage of viability reduction in relation to the negative control is described above. The negative control (C) was treated with the vehicle used to dilute the tested substance. Doxorubicin (Dox, $0.3 \mu \mathrm{g} / \mathrm{mL}$ ) was used as a positive control. The results are expressed as mean \pm standard error of measurement (S.E.M.) from two independent experiments. ${ }^{*} p<0.05$ compared to the control by ANOVA followed by student Newman-Keuls test.

$(4.5 \pm 0.7,5.5 \pm 2.1$, and $4.5 \pm 2.1$ for 5,25 , and $50 \mu \mathrm{g} / \mathrm{mL}$, respectively) in relation to the negative control $(3.5 \pm 0.7$, $p>0.05$, Figure 2(a)). On the other hand, bridges (14.6 \pm 3.9 and $27.0 \pm(2)$ and buds $(13.8 \pm 3.3)$ were observed at 25 and $50 \mu \mathrm{g} / \mathrm{mL}$ and $50 \mu \mathrm{g} / \mathrm{mL}(p<0.05)$ when compared to the negative control $(2.0 \pm 1.4$ and $5.5 \pm 3.5)$, respectively. Such chromosomal damage was corroborated by morphological features of apoptosis $(213.0 \pm 73.5$ and $337.0 \pm 57.9)$ and necrosis $(162.5 \pm 60.1$ and $189.5 \pm 40.3)$ at 25 and $50 \mu \mathrm{g} / \mathrm{mL}$ $(p<0.05$, Figure 2(b)) in the presence of cell rarefaction and vacuolization. As expected, Dox increased buds $(15.5 \pm 3.5)$ and micronuclei $(18.5 \pm 4.9)$ and caused typical findings of apoptosis $(466.0 \pm 101.8)$ and necrosis $(177.5 \pm 3.5)(p<0.05)$.

3.2. In vivo Antitumoral Activity. Experimentally transplanted mice with Sarcoma 180 cells and treated with DFMC (50 and $100 \mathrm{mg} / \mathrm{kg} /$ day) for 7 days revealed a significant reduction in tumor growth $[(0.28 \pm 0.04 \mathrm{~g}(64.8 \pm 5.3 \%)$ and $0.16 \pm 0.07 \mathrm{~g}(80.0 \pm 8.4 \%)]$ when compared to the negative control $(0.80 \pm 0.13 \mathrm{~g}$, respectively). Tumor reduction was also noted in the positive control group treated with 5 -FU $[0.11 \pm 0.03 \mathrm{~g}(82.8 \pm 4.2 \%)](p<0.05$, Table 2$)$.

The negative control group showed characteristics of malignant neoplasms consisting of round and polyhedral cells, anisocariosis, binucleation, mitoses, and different degrees of cell and nuclear pleomorphism, chromatin condensation, and extensive areas of muscle invasion (Figures 3(a)-3(d)). Tumor samples from 5-FU $25 \mathrm{mg} / \mathrm{kg} /$ day and FDCM 50 and $100 \mathrm{mg} / \mathrm{kg} /$ day also revealed the typical morphology of neoplastic cells, although rare mitoses were observed, which indicated a reduction in proliferation (Figures 3(e)-3(1)). 5-FU-treated tumors showed larger blood vessels and well vascularized sarcomas, similar to those noted in negative control tumors (Figure 3(e)). On the other hand, DFMC-treated Sarcoma 180 tumors treated with 50 and $100 \mathrm{mg} / \mathrm{kg} /$ day exhibited poorer peri- and intratumor quantities of vessels. In such tumors, vascularization was partially restricted to the adipose tissue surrounding the tumor (Figures 3(i)-3(j)).

3.3. Physiological Parameters. In the next step, we assessed macroscopic and microscopic parameters of key organs and the hematological profile of Sarcoma 180-bearing mice after treatment with DFMC. First, we found a reduction in body weight gain in DFMC-treated animals (20.6 \pm 0.8 and $21.4 \pm 1.6 \mathrm{~g}$, for 50 and $1000 \mathrm{mg} / \mathrm{kg} / \mathrm{day}$ ) in a similar way to the 5 -FU group $(20.1 \pm 0.9 \mathrm{~g})$ when compared to the negative control $(26.3 \pm 2.2 \mathrm{~g}, p<0.05$, Table 1$)$. Wet relative weight reduction of spleens was noted in both doses of DFMC $(0.2 \pm 0.08$ and $0.2 \pm 0.03 \mathrm{~g} / 100 \mathrm{~g}$ of body weight $)$ and in $5-$ FU-treated animals $(0.2 \pm 0.04 \mathrm{~g})$, but liver decrease was observed in 5-FU-treated animals only $(4.7 \pm 0.1 \mathrm{~g})$ in comparison with the negative group $(0.4 \pm 0.04 \mathrm{~g}$ and $6.0 \pm 0.4 \mathrm{~g}$, respectively, $p<0.05$ ).

Hematological analysis of DFMC-treated animals showed neutrophilia $(33.8 \pm 3.2 \%)$, lymphocytopenia $(61.5 \pm 3.6 \%)$, a reduction in eosinophils $(0.4 \pm 0.2 \%)$, and a slight increase in GOT levels $(315.3 \pm 8.9 \mathrm{U} / \mathrm{mL})(p<0.05$, Table 3$)$. Animals exposed to 5 -FU showed intense leukopenia $\left(1.6 \pm 0.3 / \mathrm{mm}^{3}\right)$ due to declines in neutrophils $(12.9 \pm 1.3 \%)$, monocytes 

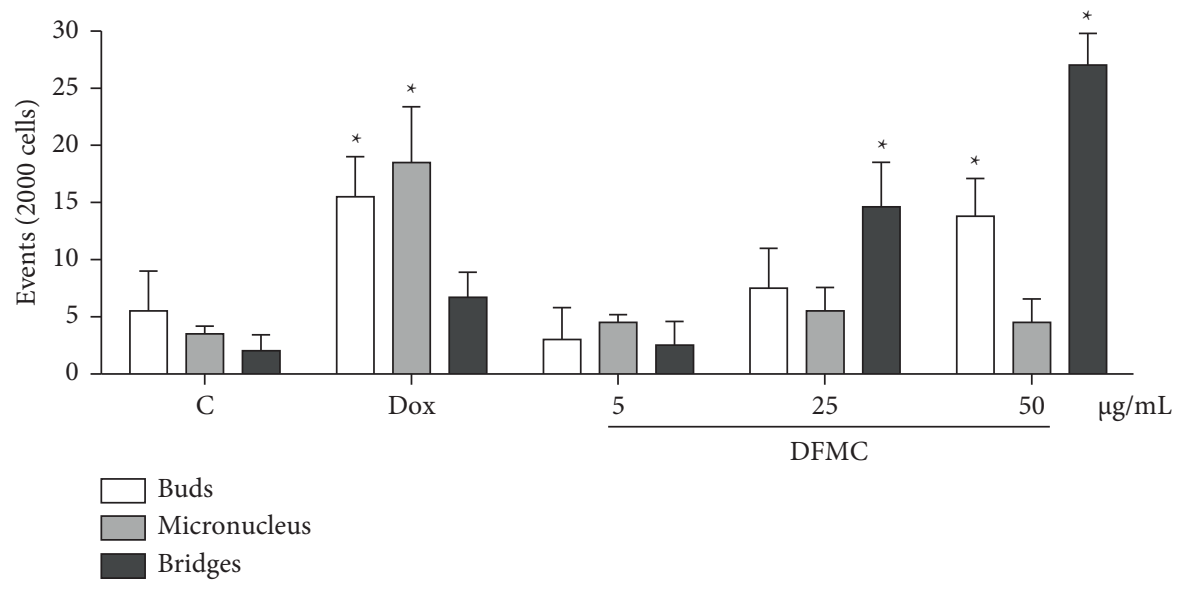

(a)

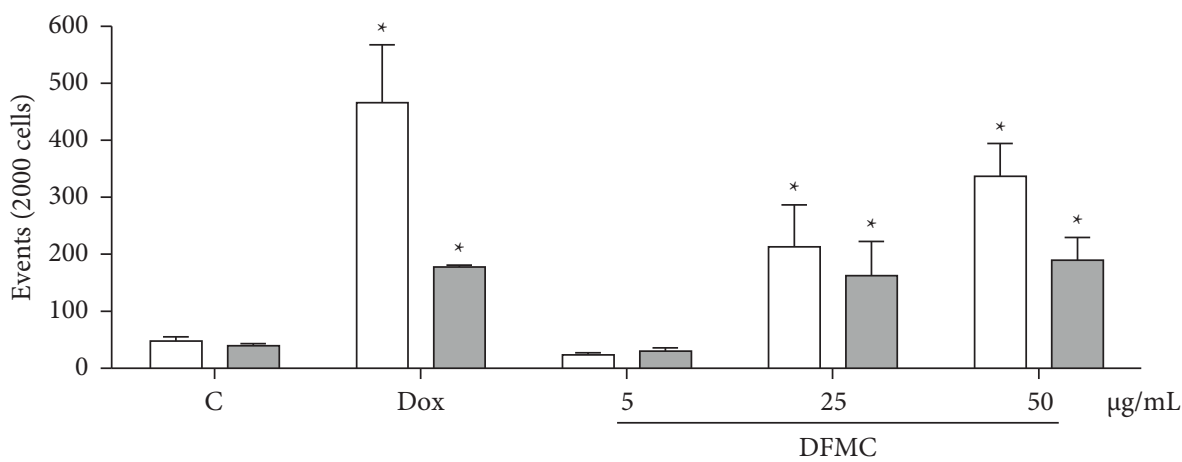

Apoptosis

Necrosis

(b)

FIGURE 2: Ex vivo chromosomal changes and cell death pattern in sarcoma 180 cells determined by micronucleus assay with cytokinesis block after $72 \mathrm{~h}$ exposure to the dichloromethane fraction from Mimosa caesalpiniifolia (DFMC) stem bark. The negative control (C) was treated with the vehicle used to dilute the tested substance (DMSO 0.1\%). Doxorubicin (Dox, $0.3 \mu \mathrm{g} / \mathrm{mL}$ ) was used as a positive control. The results are expressed as mean \pm standard error of measurement (S.E.M.) from two independent experiments. ${ }^{*} p<0.05$ compared to the control by ANOVA followed by student Newman-Keuls test.

TABLE 2: Effect of the dichloromethane fraction from Mimosa caesalpiniifolia (DFMC) stem bark on the relative weight of key organs and on the tumor growth of sarcoma 180-bearing swiss mice after 7 days of intraperitoneal treatment.

\begin{tabular}{|c|c|c|c|c|c|c|c|c|c|}
\hline Substance & $\begin{array}{c}\text { Dose }(\mathrm{mg} / \mathrm{kg} / \\
\text { day) }\end{array}$ & $\begin{array}{l}\text { Mice weight } \\
(\mathrm{g})\end{array}$ & Liver & $\begin{array}{r}\text { Kidney } \\
\text { g/10 }\end{array}$ & $\begin{array}{c}\text { Spleen } \\
0 \text { g body we }\end{array}$ & $\begin{array}{l}\text { Stomach } \\
\text { eight }\end{array}$ & Lungs & Tumor (g) & $\begin{array}{c}\text { Tumor inhibition } \\
(\%)\end{array}$ \\
\hline $\begin{array}{l}\text { Negative } \\
\text { control }\end{array}$ & - & $26.3 \pm 2.2$ & $6.0 \pm 0.4$ & $1.1 \pm 0.1$ & $0.4 \pm 0.04$ & $1.0 \pm 0.1$ & $0.8 \pm 0.1$ & $0.80 \pm 0.13$ & - \\
\hline 5-FU & 25 & $20.1 \pm 0.9^{*}$ & $4.7 \pm 0.1^{*}$ & $1.2 \pm 0.1$ & $0.2 \pm 0.04^{*}$ & $1.1 \pm 0.1$ & $0.8 \pm 0.1$ & $0.11 \pm 0.03^{*}$ & $82.8 \pm 4.2^{*}$ \\
\hline DFMC & $\begin{array}{c}50 \\
100 \\
\end{array}$ & $\begin{array}{l}20.6 \pm 0.8^{*} \\
21.4 \pm 1.0^{*}\end{array}$ & $\begin{array}{l}5.8 \pm 0.2 \\
5.9 \pm 0.2\end{array}$ & $\begin{array}{l}1.2 \pm 0.1 \\
1.3 \pm 0.1\end{array}$ & $\begin{array}{l}0.2 \pm 0.08^{*} \\
0.2 \pm 0.03^{*}\end{array}$ & $\begin{array}{l}1.1 \pm 0.1 \\
1.2 \pm 0.5\end{array}$ & $\begin{array}{l}1.0 \pm 0.2 \\
0.8 \pm 0.1\end{array}$ & $\begin{array}{l}0.28 \pm 0.04^{*} \\
0.16 \pm 0.07^{*}\end{array}$ & $\begin{array}{l}64.8 \pm 5.3^{*} \\
80.0 \pm 8.4^{*}\end{array}$ \\
\hline
\end{tabular}

Values are means \pm S.E.M. ( $n=10$ animals/group). The negative control was treated with the vehicle used to dilute the drug (DMSO 5\%). 5-Fluorouracil (5-FU) was used as positive control. ${ }^{*} p<0.05$ compared with the negative control by ANOVA followed by Newman-Keuls test.

$(0.6 \pm 0.2 \%)$ and eosinophils $(0.6 \pm 0.3 \%)$ compared to the animals from the negative group $\left(5.1 \pm 0.4 / \mathrm{mm}^{3}, 18.8 \pm 2.8 \%\right.$, $1.8 \pm 0.3 \%$ and $1.8 \pm 0.4 \%$, respectively, $p<0.05)$.

3.4. Histological Alterations. Animals from the negative control group and treated with DFMC (50 and $100 \mathrm{mg} / \mathrm{kg} /$ day) did not show signs of toxicity, with similarity among organs from these groups. Livers did not exhibit hyperplasia, hemosiderin pigments, infiltration of leukocytes, cell swelling, portal congestion, or areas of necrosis, although microesteatosis was detected in all groups (Figure 4(a)). Kidneys present no swelling, tubular degeneration, vascular congestion, or necrosis focus (Figure 4(b)); in hearts, there were no areas of degeneration or fibroblasts proliferation and striations were clearly visible (Figure 4(c)); lungs showed bronchioles and 


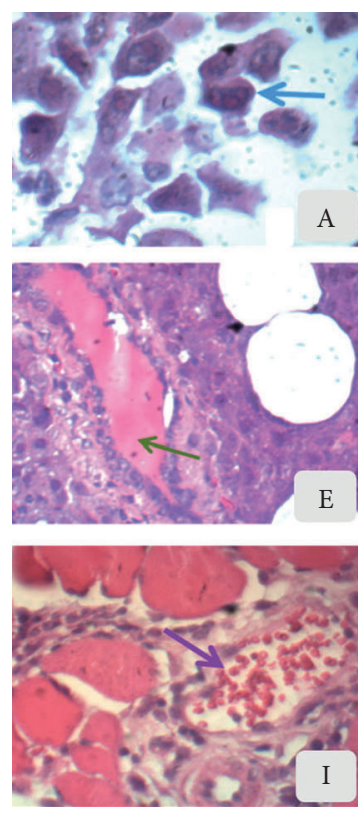

$\longleftarrow$ Muscular invasion

$\longleftarrow$ Binucleation
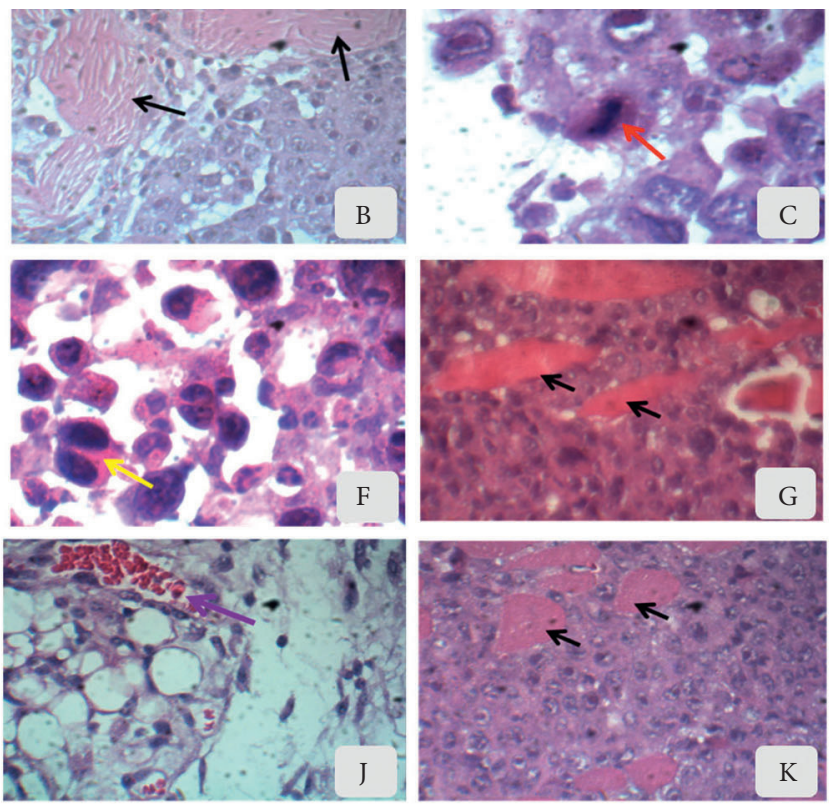

$\longleftarrow$ Chromation condensation
$\longleftarrow$ Mitosis
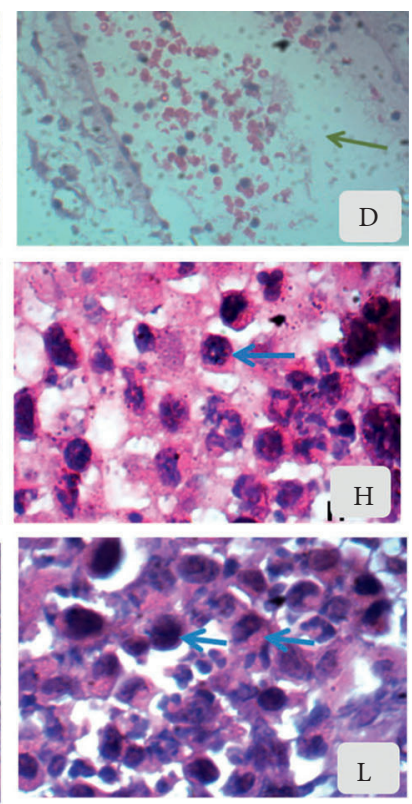

$\longleftarrow$ Intratumoral vessels

$\longleftarrow$ Microenvironment vessels

Figure 3: Morphology of sarcoma 180 tumor cells from swiss mice after 7 days of treatment with dichloromethane fraction from Mimosa caesalpiniifolia stem bark. Animals were treated by intraperitoneal injection ( $50 \mathrm{mg} / \mathrm{kg} / \mathrm{day}$ : g, h, and i; $100 \mathrm{mg} / \mathrm{kg} / \mathrm{day}: \mathrm{j}, \mathrm{k}$, and l). The negative control was treated with the vehicle used to dilute the substance (DMSO 5\%: a-d). 5-Fluorouracil was used as a positive control (e and f). Hematoxylin-eosin staining. Light microscopy magnification, 100x-400x.

TABLE 3: Hematological and biochemical parameters of mice intraperitoneally treated with dichloromethane fraction from Mimosa caesalpiniifolia stem bark for 7 days.

\begin{tabular}{|c|c|c|c|c|}
\hline \multirow[t]{2}{*}{ Parameters } & \multirow[t]{2}{*}{ Negative control } & \multirow[t]{2}{*}{5 -FU $25 \mathrm{mg} / \mathrm{kg} /$ day } & \multicolumn{2}{|c|}{$\begin{array}{l}\text { Dichloromethane fraction from Mimosa } \\
\text { caesalpiniifolia }\end{array}$} \\
\hline & & & $50 \mathrm{mg} / \mathrm{kg} /$ day & $100 \mathrm{mg} / \mathrm{kg} /$ day \\
\hline Erythrocytes $\left(\mathrm{mm}^{3}\right)$ & $4.5 \pm 0.2$ & $4.4 \pm 0.2$ & $5.0 \pm 0.1$ & $4.9 \pm 0.2$ \\
\hline Hemoglobin (g/dL) & $13.6 \pm 0.7$ & $13.3 \pm 0.8$ & $15.4 \pm 0.4$ & $15.0 \pm 0.7$ \\
\hline Hematocrit (\%) & $40.7 \pm 2.3$ & $40.1 \pm 2.3$ & $46.3 \pm 1.1$ & $44.9 \pm 2.2$ \\
\hline $\mathrm{VCM}(\mathrm{fL})$ & $90.8 \pm 0.5$ & $90.6 \pm 0.6$ & $91.8 \pm 0.3$ & $91.6 \pm 0.5$ \\
\hline $\mathrm{HCM}(\mathrm{pg})$ & $30.2 \pm 0.2$ & $30.2 \pm 0.2$ & $30.5 \pm 0.1$ & $30.5 \pm 0.2$ \\
\hline $\mathrm{CHCM}(\mathrm{g} / \mathrm{dL})$ & $33.3 \pm 0.1$ & $33.1 \pm 0.1$ & $33.2 \pm 0.1$ & $33.3 \pm 0.1$ \\
\hline Platelets $\left(\mathrm{mm}^{3}\right)$ & $3.6 \pm 0.5$ & $2.9 \pm 0.2$ & $3.4 \pm 0.2$ & $3.4 \pm 0.2$ \\
\hline Total leukocytes $\left(\mathrm{mm}^{3}\right)$ & $5.1 \pm 0.4$ & $1.6 \pm 0.3^{*}$ & $5.4 \pm 0.6$ & $4.9 \pm 0.7$ \\
\hline Neutrophils (\%) & $18.8 \pm 2.8$ & $12.9 \pm 1.3^{*}$ & $23.3 \pm 4.1$ & $33.8 \pm 3.2^{*}$ \\
\hline Rods (\%) & $0.4 \pm 0.2$ & $0.4 \pm 0.3$ & $0.6 \pm 0.2$ & $1.8 \pm 0.7$ \\
\hline Lymphocytes (\%) & $77.3 \pm 3.0$ & $85.6 \pm 1.8$ & $73.7 \pm 4.1$ & $61.5 \pm 3.6^{*}$ \\
\hline Monocytes (\%) & $1.8 \pm 0.3$ & $0.6 \pm 0.2^{*}$ & $1.7 \pm 0.6$ & $2.6 \pm 0.8$ \\
\hline Eosinophils (\%) & $1.8 \pm 0.4$ & $0.6 \pm 0.3^{*}$ & $0.7 \pm 0.3^{*}$ & $0.4 \pm 0.2^{*}$ \\
\hline Basophils (\%) & 0.0 & 0.0 & 0.0 & 0.0 \\
\hline GOT $(\mathrm{U} / \mathrm{mL})$ & $286.9 \pm 5.8$ & $303.2 \pm 7.6$ & $280.8 \pm 9.1$ & $315.3 \pm 8.9^{*}$ \\
\hline GTP (U/mL) & $158.8 \pm 2.6$ & $157.5 \pm 4.3$ & $161.6 \pm 5.0$ & $156.3 \pm 1.1$ \\
\hline $\operatorname{ALP}(\mathrm{U} / \mathrm{L})$ & $112.3 \pm 5.5$ & $131.2 \pm 9.8$ & $101.2 \pm 3.4$ & $93.8 \pm 6.6$ \\
\hline Creatinine $(\mathrm{mg} / \mathrm{dL})$ & $0.5 \pm 0.05$ & $0.5 \pm 0.08$ & $0.4 \pm 0.01$ & $0.4 \pm 0.04$ \\
\hline BUN $(\mathrm{mg} / \mathrm{dL})$ & $48.9 \pm 4.2$ & $37.7 \pm 2.4$ & $41.3 \pm 6.6$ & $42.8 \pm 3.1$ \\
\hline
\end{tabular}

$\mathrm{MCH}$, mean corpuscular hemoglobin; MCV, mean corpuscular volume; MCHC, mean corpuscular hemoglobin concentration; BUN, blood urea nitrogen; GOT, glutamate oxaloacetate transaminase; GPT, glutamate pyruvate transaminase; ALP, alkaline phosphatase. Values are means \pm S.E.M. $(n=10$ animals/group). The negative control was treated with the vehicle used to dilute the drug (DMSO 5\%). 5-Fluorouracil (5-FU) was used as positive control. ${ }^{*} P<0.05$ compared with the negative control by ANOVA followed by Newman-Keuls test.

visible alveolar spaces, absence of mono and polymorphonuclear cells or areas of necrosis (Figure 4(d)); stomachs showed normal mucosa and submucosa, absence of hemorrhagic streaks, a cardiac region with a keratinized squamous lining, no changes in chorion and easy visualization of parietal and main cells (Figure 4(e)). Spleens showed 

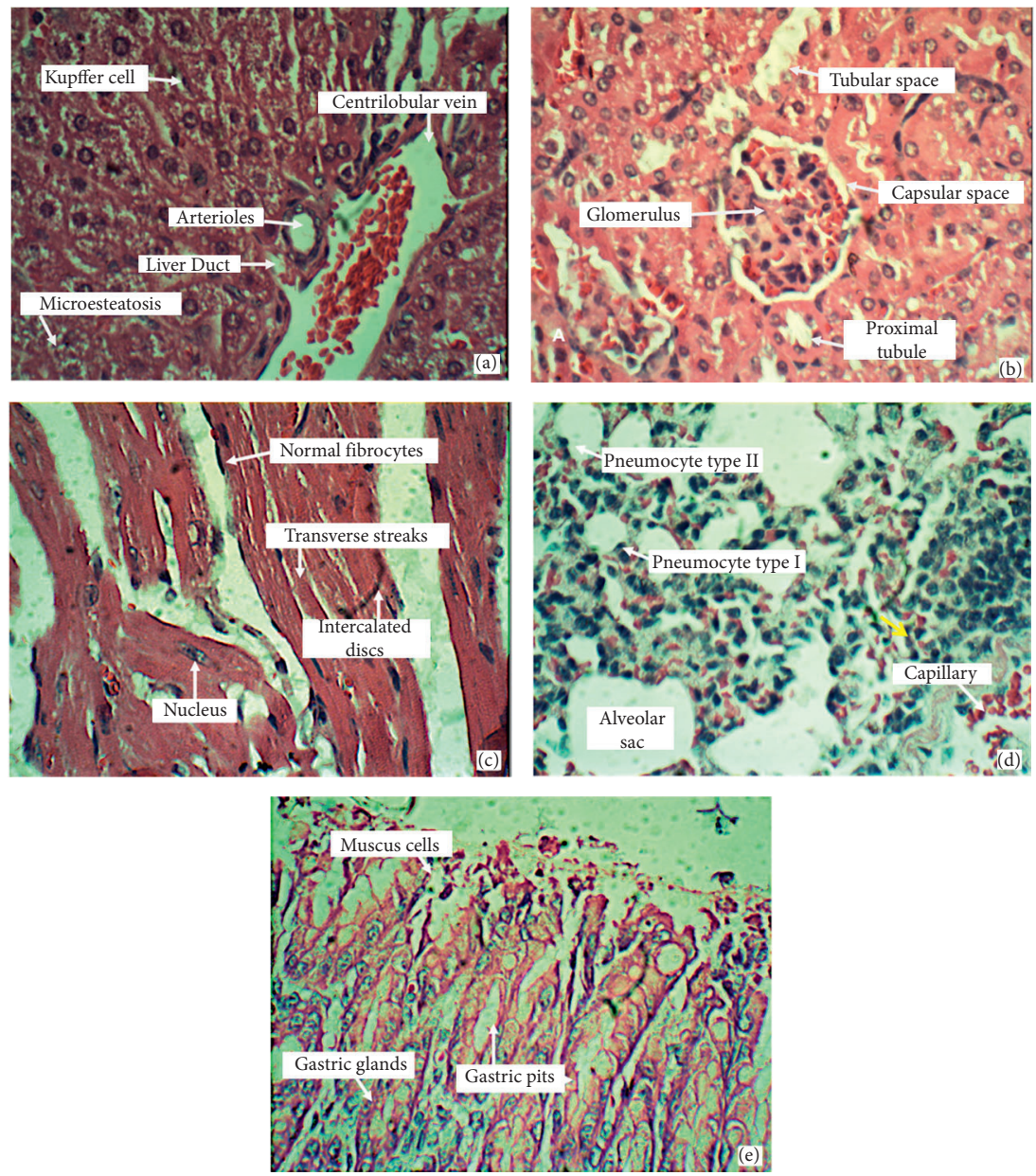

FiguRE 4: General morphology of livers (a), kidneys (b), hearts (c), lungs (d), and stomachs (e) from Swiss mice after 7 days of treatment with dichloromethane fraction from Mimosa caesalpiniifolia stem bark (50 or $100 \mathrm{mg} / \mathrm{kg} /$ day) or vehicle used to dilute the substance (DMSO 5\%). Important changes among these groups were not observed. Hematoxylin-eosin staining. Light microscopy magnification, 400x.

megakaryocytes and hemosiderin pigments in all groups. Disorganization of lymphoid follicles and relative reduction of the white pulp were observed in the 5-FU (Figure 5(b)) and DFMC-treated animals (Figures 5(c) and 5(d)). On the other hand, 5-FU-treated animals showed slight hepatocyte swelling and suggestion of mild changes in fatty metabolism since macroesteatosis was noted, and kidneys presented swelling of tubular cells and foci of atrophic glomeruli (results not shown).

3.5. In vivo Chromosomal Damage. DFMC increased micronucleated polychromatic erythrocytes in the bone marrow of mice in a dose-dependent manner (50 and $100 \mathrm{mg} / \mathrm{kg} /$ day: $11.5 \pm 0.2$ and $26.0 \pm 2.1$, respectively) compared to the vehicle group $(2.8 \pm 0.2, p<0.05)$. As expected, $25 \mathrm{mg} / \mathrm{kg} /$ day $5-\mathrm{FU}$ caused clastogenic effects $(14.0 \pm 0.1, p<0.05)$.

\section{Discussion}

In the last century, the development of cytotoxic agents has revolutionized anticancer therapy. Adjuvant treatments with antiproliferative substances have demonstrated an indisputable advantage when compared to traditional treatments based on surgery and monochemotherapy, making it possible to cure neoplasms such as acute childhood leukemia, Hodgkin and non-Hodgkin's lymphomas, and germ cell tumors [31, 32]. However, the great heterogeneity of tumor cells makes treatment difficult and facilitates the manifestation of resistance [33], which stimulates the search for new chemotherapeutic agents.

Initially, the antiproliferative action of DFMC was evaluated in primary cultures of Sarcoma 180 cells. In vitro cytotoxicity tests in cell cultures are important for the evaluation of antitumor agents, and at least during the screening phase, they have reduced in vivo tests on animals. In addition, they are widely used as alternative methods to pharmacological tests on isolated organs [26, 34]. Herein, DFMC and its majority compound betulinic acid revealed similar cytotoxic capacity on S180 cells by Alamar blue assay, whose action was confirmed by cell viability reduction in trypan blue exclusion tests. Some reports, including the American National Cancer Institute (NCI-USA) [35], suggest that $\mathrm{IC}_{50}$ values around $30 \mu \mathrm{g} / \mathrm{mL}$ are a suitable outcome to consider extracts and fractions promising substances for further purification and biological studies $[12,15]$. Recently, we reported that DFMC 

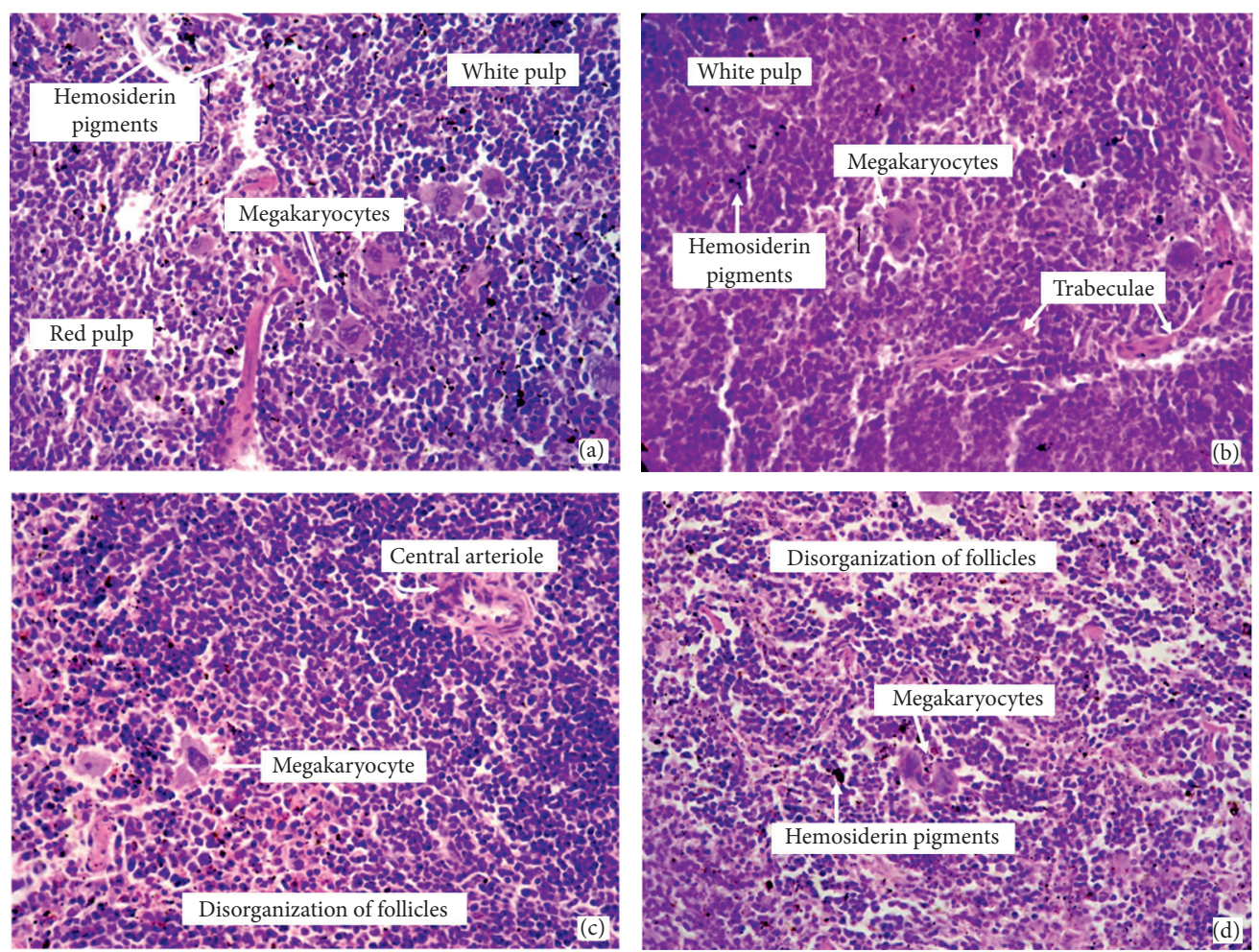

Figure 5: Spleen morphology of Swiss mice after 7 days of treatment with dichloromethane fraction from Mimosa caesalpiniifolia stem bark $(50 \mathrm{mg} / \mathrm{kg} /$ day (c); $100 \mathrm{mg} / \mathrm{kg} /$ day (d)), vehicle used to dilute the substance DMSO 5\% (a) or 5-fluorouracil $25 \mathrm{mg} / \mathrm{kg} / \mathrm{day}$ (b). Hematoxylineosin staining. Light microscopy magnification, 400x.

has higher cytotoxic action against different types of tumor tissues (promyelocytic leukemia, HL-60; glioblastoma, SF295; ovarian, OVCAR-8; colon, HCT-116) than hexane and water extracts. DFMC did not produce hemolysis and showed higher potential as a cytotoxic agent than betulinic acid for the SF-295 and HL-60 lines [20, 36], corroborating the findings described here for S180 cells.

Phytochemical investigation of extracts from Mimosa species revealed the existence of terpenes, flavonoids, steroids, phenols (especially tannins), and fatty acid derivatives in different parts of the plant (leaves, fruits, flowers, branches, and stem bark) [36-40], mainly betulinic acid, lupeol, phytol, lactic acid, $\alpha$-tocopherol, stigmasterol, $\beta$-sitosterol, sitostenone, and stigmasta-4,22-dien-3-one, which had been identified in dichloromethane, ethanolic, and hexane fractions of leaves and barks from M. caesalpiniifolia $[15,36,40]$, suggesting that the antiproliferative potential of DFMC may be attributed, at least in part, to its chemopreventive action. In this context, Silva et al. [15] stated the scavenger activity of $M$. caesalpiniifolia extracts, whose presence of phenolic compounds was confirmed by ultraviolet-visible spectroscopy and thin-layer chromatography.

Betulinic acid, a naturally occurring pentacyclic triterpenoid, is the main compound in the fraction $(\sim 70.3 \%)$ $[15,23]$, and both samples (DFMC and isolated molecule) have similar bioactivity on S180 cells $(p>0.05)$, confirming reports about the antiproliferative action of betulinic acid in many types of cancers [41-50].

To complement the ex vivo cytotoxic analysis on S180 tumor cells and in vivo pharmacological safety, cytokinesis- block micronucleus (CBMN) assays were performed to measure micronuclei quantification and DNA damage in mammalian cell cultures [28]. Apart from the evaluation of micronuclei, the CBMN cytome assay allows the assessment of other relevant biodosimetric markers: nucleoplasmic bridges, nuclear buds, proportion of dividing cells (parameter of cytostasis), and cells undergoing apoptosis and necrosis (parameters of cytotoxicity). Therefore, this technique was updated to detect chromosomal breaks, DNA rearrangements, chromosomal losses, cytostasis, and to separate types of cell death $[25,28,51,52]$. Therefore, for the first time, an increase in chromosomal damage represented by (i) nucleoplasm bridges: a biomarker of dicentric chromosomes, resulting from the fusion of the final telomeres after DNA double-strand breaks or DNA misrepair/rearrangements; (ii) buds: a biomarker of gene amplification and originating from interstitial or terminal acentric fragments; and (iii) morphological features of apoptosis and necrosis in S180 cells at higher concentrations of DFMC was noted. Meanwhile, both doses of DFMC also induced the emergence of micronucleated polychromatic erythrocytes in bone marrow. Previously, Silva et al. [23] reported an ethanolic extract from $M$. caesalpiniifolia leaves with maximum cytotoxicity on breast carcinoma MCF-7 cells at $320 \mu \mathrm{g} / \mathrm{mL}$ and morphological changes suggestive of apoptosis, including DNA fragmentation and nuclear chromatin condensation.

Recently, we also showed that micronuclei formation and changes indicating mutagenic index in DFMC-treated roots were not detected, although this fraction has inhibited 
growth of Allium cepa roots and increase amount of bridges in dividing meristematic cells, which indicates capacity for mitotic index reduction as seen as dropping of cells at metaphase, anaphase, and telophase phases and cycle arrest at prophase [15]. Regardless, it is likely that DNA/chromosomal damage is a sign of nonselective mechanism(s) in tumor or normal dividing cells. Therefore, in vitro (bridges and buds) and in vivo (micronucleus) clastogenic findings led to cell cycle arrest as a "cellular escape" from death, mainly if we consider the antiproliferative action of DFMC on human normal leukocytes well [15].

Indeed, antineoplastic agents induce DNA strand breaks in mammalian cells, as seen with inhibitors of topoisomerase I (camptothecin) and topoisomerase II (etoposide) [53] and 5-FU. 5-FU is a widely used antimetabolite to treat breast adenocarcinomas and cancers of the gastrointestinal tract and head and neck due to its inhibitory action on the enzyme thymidylate synthase [54], among other mechanisms, despite its unblemished in vivo clastogenic activity [55]. However, genotoxicity does not mean mutagenicity because some genome injuries are biochemically fixed, which indicates that antineoplastic acute toxic consequences (e.g., inhibition of growth and cell division) are not automatically linked to chromosomal loss/impairments [56].

The cytotoxic activity on cancer cells using in vitro models may not reflect in vivo findings, since the latter considers pharmacokinetic and pharmacodynamic variables, such as ligand binding to specific receptors, downstream cascade, involvement of second messengers, water/ lipid solubility, bioavailability, first-pass metabolism, and renal excretion $[57,58]$. Therefore, combining these two types of scientific tools is appropriate for a more complete assessment of a substance with antiproliferative action. For the first time, the amazing antitumor action of a dichloromethane fraction from $M$. caesalpiniifolia stem bark on in vivo proliferating Sarcoma 180 cells was demonstrated. In vivo studies have already shown that betulinic acid inhibits the growth of human ovarian IGROV-1 carcinoma xenographic tumors at $100 \mathrm{mg} / \mathrm{kg} /$ day and increases the survival rate of mice [46].

No specific changes were noted during histopathological analysis of the Sarcoma 180 tumors [34], but it is important to emphasize that local vascularization from DFMC-treated animals was predominantly confined to the adipose tissue surrounding the tumors. These unexpected findings were not described before and suggest that the fraction interferes with the cell cycle of Sarcoma 180 cells and inhibits angiogenesis, which obviously alters the stromal environment, such as the local $\mathrm{pH}$, partial pressure of oxygen and carbon dioxide, input of nutrients/growth factors, and cleaning of metabolic residues [57], all essential primary conditions for cellular division and tumor growth. Molecular studies are underway to confirm such antiangiogenic potential. These data corroborate our findings about the biomedical potential of M. caesalpiniifolia and inspired us to assess the pharmacological safety profile of the fraction, taking into consideration its promising phytotherapy properties.

The development of new (phyto)pharmaceutical products includes not only pharmacodynamic discoveries but also essential data about the pharmacokinetics profile, therapeutic window, and pharmacological safety, including systemic and genetic toxicology $[58,59]$. These assessments allow the exclusion of undesirable drug candidates and save time, material and human resources. In the case of plant toxicity/poisoning, its harmful action must be proven experimentally. For humans, this experimental reproduction should be carried out in the same animal species, naturally affected, or related species (e.g., mice and rats), although different susceptibilities to the effects of toxic herbals among species are a common mark $[60,61]$.

Acute signs of systemic toxicity are loss of body mass and expansion or involution of key organs in mammals exposed to an investigational drug [62]. Weight loss is one of the most common side effects after chemotherapy cycles with 5FU or doxorubicin, since the gastrointestinal system is one of the main nonspecific targets of nontarget antiproliferative agents, causing seasickness, suppression of appetite, vomiting, and diarrhea [63]. Loss of body weight and reduction of spleens were macroscopic manifestations found in the 5FU- and DFMC-treated groups, but signs of diarrhea were not seen in the DFMC-treated groups. Spleen diminution is another very common side effect found in S180-bearing mice under experimental treatment with promising antitumoral substances $[26,64]$ and reflects lymphocytopenia seen in 5-FU- and DFMC-treated groups and strong leukopenia in 5-FU-treated mice, which was confirmed by disorganization of lymphoid follicles and size reduction of white pulps.

In vivo toxicological studies with DFMC were not found in the literature, but oral subacute treatment of rats for 32 days with $750 \mathrm{mg} / \mathrm{kg} /$ day ethanolic extract from M. caesalpiniifolia leaves caused weight loss, hepatomegaly, and an increase in adrenal and pituitary glands [40], but serum biochemical evaluation (alkaline phosphatase, GOT, urea, and creatinine) did not identify renal or liver changes. On the other hand, we noted that the $100 \mathrm{mg} / \mathrm{kg} /$ day DFMC-treated group revealed a slight but significant increase in GOT.

Transaminases (GOT and GTP) are found in all human systems and many organs, but they are more present in the cytoplasm (100\% GTP/20\% GOT) or mitochondria $(80 \%$ GOT) of hepatocytes, since they catalyze transamination reactions, working central providers of secondary metabolites to the citric acid cycle. Any type of liver injury may sensibly increase serum GTP concentrations, a classic biomarker to assess acute or chronic hepatic damage, but its origin can have kidney, heart, or muscle reasons because these organs also possess higher GTP concentrations in comparison with other tissues [65]. On the other hand, GOT is more abundant in heart, skeletal muscle, kidneys, brain, and red blood cells [66], with lower concentrations in skeletal muscle and kidney. Although GTP is more specific for detecting liver damage, ischemic or toxic damage to zone 3 of the hepatic acinus may change GOT levels since this region has greater GOT concentrations [65].

Histological changes were not found in livers from DFMC-treated animals. Thus, it is probable that higher levels of GOT may be associated with muscle damage and/ 


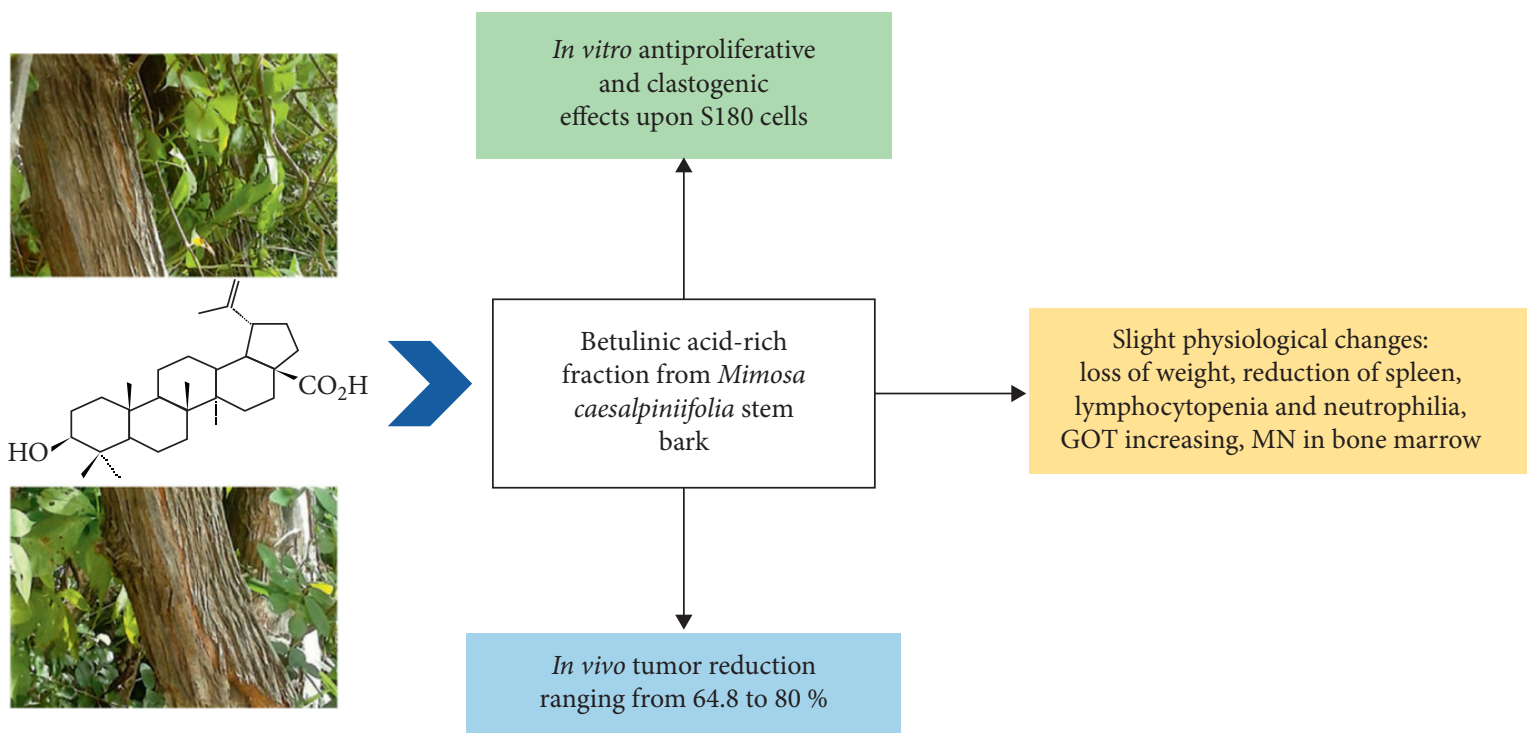

FIgURE 6: Summary of the antiproliferative, genotoxic, antitumoral, and toxicological effects of a betulinic acid-rich fraction from Mimosa caesalpiniifolia stem bark.

or trauma after continual intraperitoneal injections because this procedure can result in aminotransferase release, and an increase in GOT is common in such situations [66].

The majority of clinically available anticancer medications provoke strong side effects, especially suppression of bone marrow and immune response, toxicity on hepatocytes, cardiac myocytes and enterocytes, mucositis, weight and hair loss (incidence of 65\%), opportunistic infections, seasickness, vomiting, chemotherapy-related anorexia, peripheral neuropatia, and tiredness [33, 63, 67-69], whose types and intensity depend on the mechanism(s) of action and idiosyncratic reactions. Based on nonsevere organic findings, we believe that the preclinical general anticancer properties of DFMC are not threatened by toxicological effects (Figure 6).

\section{Conclusions}

A betulinic acid-rich fraction from Mimosa caesalpiniifolia stem bark showed, for the first time, in vitro and in vivo antiproliferative capacity on Sarcoma 180 tumors and induction of nonselective chromosomal damage (bridges, buds, and micronucleus) to dividing murine cells. Such antimitotic action was associated with detectible physiological changes, indicating side effects (loss of weight, reduction of spleen, lymphocytopenia, and neutrophilia and increasing of GOT and micronucleus in bone marrow). These biomedical discoveries validate the ethnopharmacological reputation of Mimosa species as emerging phytotherapy sources of lead molecules.

\section{Data Availability}

The data sets used and/or analyzed during the present study are available from the corresponding author on reasonable request.

\section{Conflicts of Interest}

The authors declare that there are no conflicts of interest regarding the publication of this paper.

\section{Acknowledgments}

Paulo Michel Pinheiro Ferreira is grateful to the public Brazilian agency "Conselho Nacional de Desenvolvimento Científico e Tecnológico" [CNPq (\#303247/2019-3)] for his personal scholarship. The authors also thank Leane Brunelle dos Santos Alves for technical assistance and the Postgraduate Program in Pharmaceutical Sciences (PPGCF, Teresina, Piauí, Brazil) for structural support.

\section{References}

[1] D. J. Newman and G. M. Cragg, "Natural products as sources of new drugs over the 30 years from 1981 to 2010," Journal of Natural Products, vol. 75, no. 3, pp. 311-335, 2012.

[2] Fundação de Amparo à Pesquisa do Estado de São Paulo, Biota Program, Brazilian Biodiversity Research, A Promising Future, FAPESP, São Paulo, Brazil, 2020, https://fapesp.br/ biota/.

[3] Biodiversity Finance Initiative (BIOFIN), Brazil, September 2020, https://biodiversityfinance.net/brazil.

[4] Brazil, Ministry of Health, Health Care Secretariat, Department of Primary Care, "Food guide for the Brazilian population," Brasília, Ministry of Health, September 2020, https:// bvsms.saude.gov.br/bvs/publicacoes/guia_alimentar_ populacao_brasileira_2ed.pdf.

[5] Brazil, Ministry of Environment, "The Status of Brazilian Biological Diversity," First National Report for the Convention on Biological Diversity - Brazil, September 2020, https:// www.mma.gov.br/component/k2/item/7927.html.

[6] M. Valli, M. Pivatto, A. Danuello et al., "Tropical biodiversity: has it been a potential source of secondary metabolites useful for medicinal chemistry?" Química Nova, vol. 35, no. 11, pp. 2278-2287, 2012. 
[7] J. B. A. Pereira, M. M. Rodrigues, I. R. Morais et al., "The therapeutic role of the program farmacia viva and the medicinal plants in the center-south of Piauí," Revista Brasileira de Plantas Medicinais, vol. 17, no. 4, pp. 550-561, 2015.

[8] M. Valli and V. S. Bolzani, "Natural products: perspectives and challenges for use of Brazilian plant species in the bioeconomy," Anais da Academia Brasileira de Ciências, vol. 91, no. 3, Article ID e20190208, 2019.

[9] L. P. Queiroz, A. Rapini, and A. M. Giulietti, Rumo ao Amplo Conhecimento da Biodiversidade do Semi-árido Brasileiro, Ministério da Ciência e Tecnologia, Brasília, Distrito Federal, 2020, http://www.terrabrasilis.org.br/ecotecadigital/pdf/ rumo-ao-amplo-conhecimento-da-biodiversidade-do-semiarido-brasileiro.pdf.

[10] Brasil, Ministério da Integração Nacional, "Resolução N ${ }^{\circ} 107 /$ 2017," Superintendência do Desenvolvimento do Nordeste, 2019, http://sudene.gov.br/images/2017/arquivos/Resolucao107-2017.pdf.

[11] M. I. G. Silva, C. T. V. d. Melo, L. F. Vasconcelos, A. M. R. d. Carvalho, and F. C. F. Sousa, "Bioactivity and potential therapeutic benefits of some medicinal plants from the Caatinga (semi-arid) vegetation of Northeast Brazil: a review of the literature," Revista Brasileira de Farmacognosia, vol. 22, no. 1, pp. 193-207, 2012.

[12] P. M. P. Ferreira, D. F. Farias, M. P. Viana et al., "Study of the antiproliferative potential of seed extracts from Northeastern Brazilian plants," Anais da Academia Brasileira de Ciências, vol. 83, no. 3, pp. 1045-1058, 2011.

[13] D. F. Farias, T. M. Souza, M. P. Viana et al., "Antibacterial, antioxidant, and anticholinesterase activities of plant seed extracts from Brazilian semiarid region," BioMed Research International, vol. 2013, Article ID 510736, 9 pages, 2013.

[14] N. M. Lima, V. A. La Porta, and F. A. La Porta, "Chemodiversity, bioactivity and chemosystematics of the genus Inga (Fabaceae): a brief review," Revista Virtual de Química, vol. 10, no. 3, pp. 459-473, 2018.

[15] J. N. Silva, N. B. N. Monção, R. R. S. Farias et al., "Toxicological, chemopreventive, and cytotoxic potentialities of rare vegetal species and supporting findings for the Brazilian Unified Health System (SUS)," Journal of Toxicology and Environmental Health, Part A, vol. 83, no. 13-14, pp. 525-545, 2020.

[16] P. E. R. Carvalho, "Sabiá, Mimosa caesalpiniifolia," Edited by C. Técnica and E. Florestas, Eds., Embrapa, Colombo, Brasil, 2007.

[17] U. P. de Albuquerque, P. M. de Medeiros, A. L. S. de Almeida et al., "Medicinal plants of the Caatinga (semi-arid) vegetation of NE Brazil: a quantitative approach," Journal of Ethnopharmacology, vol. 114, no. 3, pp. 325-354, 2007.

[18] S. M. de Sousa, A. C. Reis, and L. F. Viccini, "Polyploidy, B chromosomes, and heterochromatin characterization of Mimosa caesalpiniifolia Benth. (Fabaceae-Mimosoideae)," Tree Genetics \& Genomes, vol. 9, no. 2, pp. 613-619, 2013.

[19] J. B. S. Araújo and J. B. Paes, "Natural wood resistance of Mimosa caesalpiniifolia in field testing," Floresta e Ambiente, vol. 25, no. 2, 2018.

[20] M. J. Dias Silva, A. M. Simonet, N. C. Silva, A. L. T. Dias, W. Vilegas, and F. A. Macías, "Bioassay-guided isolation of fungistatic compounds from Mimosa caesalpiniifolia leaves," Journal of Natural Products, vol. 82, no. 6, pp. 1496-1502, 2019.

[21] D. L. Horn, D. Neofytos, E. J. Anaissie et al., "Epidemiology and outcomes of candidemia in 2019 patients: data from the prospective antifungal therapy alliance registry," Clinical Infectious Diseases, vol. 48, no. 12, pp. 1695-1703, 2009.

[22] M. E. P. Santos, L. H. P. Moura, M. B. Mendes et al., "Hypotensive and vasorelaxant effects induced by the ethanolic extract of the Mimosa caesalpiniifolia Benth. (Mimosaceae) inflorescences in normotensive rats," Journal of Ethnopharmacology, vol. 164, pp. 120-128, 2015.

[23] M. J. D. Silva, A. J. S. Carvalho, C. Q. Rocha, W. Vilegas, M. A. Silva, and C. M. C. P. Gouvêa, "Ethanolic extract of Mimosa caesalpiniifolia leaves: chemical characterization and cytotoxic effect on human breast cancer MCF-7 cell line," South African Journal of Botany, vol. 93, pp. 64-69, 2014.

[24] D. Renzi, M. Valtolina, and R. Forster, "The evaluation of a multi-endpoint cytotoxicity assay system," Alternatives to Laboratory Animals, vol. 21, no. 1, pp. 89-96, 1993.

[25] M. Fenech, "Cytokinesis-block micronucleus cytome assay," Nature Protocols, vol. 2, no. 5, pp. 1084-1104, 2007.

[26] P. M. P. Ferreira, D. P. Bezerra, J. N. Silva et al., "Preclinical anticancer effectiveness of a fraction from Casearia sylvestris and its component Casearin $\mathrm{X}$ : in vivo and ex vivo methods and microscopy examinations," Journal of Ethnopharmacology, vol. 186, pp. 270-279, 2016.

[27] B. H. Waynforth, Injection Techniques: Experimental and Surgical Techniques in the Rat, Academic Press, London, UK, 1980.

[28] W. Schmid, "The micronucleus test," Mutation Research: Environmental Mutagenesis \& Related Subjects, vol. 31, no. 1, pp. 9-15, 1975.

[29] J. Heddle, "A rapid in vivo test for chromosomal damage," Mutation Research: Fundamental and Molecular Mechanisms of Mutagenesis, vol. 18, no. 2, pp. 187-190, 1973.

[30] Organisation for Economic Co-operation and Development, "Test No. 487: in vitro mammalian cell micronucleus test," in Guidelines for the Testing of Chemicals, Section 4OECD, Paris, France, 2020, https://www.oecd.org/chemicalsafety/test-no487-in vitro-mammalian-cell-micronucleus-test9789264264861-en.htm.

[31] M. V. N. Souza, A. C. Pinheiro, M. L. Ferreira, R. S. B. Gonçalves, and C. H. C. Lima, "Natural products in advance clinical trials applied to cancer," Revista Fitos, vol. 3, pp. 25-41, 2007.

[32] G. F. V. Ismael, D. D. Rosa, M. S. Mano, and A. Awada, "Novel cytotoxic drugs: old challenges, new solutions," Cancer Treatment Reviews, vol. 34, no. 1, pp. 81-91, 2008.

[33] P. M. P. Ferreira and C. Pessoa, "Molecular biology of human epidermal receptors, signaling pathways and targeted therapy against cancers: new evidences and old challenges," Brazilian Journal of Pharmaceutical Sciences, vol. 53, no. 2, Article ID e16076, 2017.

[34] P. M. P. Ferreira, R. R. Drumond, C. L. S. Ramos et al., "Biologia e aplicações pré-clínicas do modelo experimental Sarcoma 180," in Análise Crítica das Ciências Biológicas e da Natureza, J. M. B. Oliveira Junior, Ed., Atena Editora, Ponta Grossa, Brazil, pp. 270-287, 2019.

[35] M. Suffness and J. M. Pezzuto, "Assays related to cancer drug discovery," in Methods in Plant Biochemistry: Assays for Bioactivity, K. Hostettmann, Ed., p. 376, Academic Press, London, UK, 1991.

[36] N. B. Monção, B. Q. Araújo, J. N. Silva et al., “Assessing chemical constituents of Mimosa caesalpiniifolia stem bark: possible bioactive components accountable for the cytotoxic effect of M. caesalpiniifolia on human tumour cell lines," Molecules (Basel, Switzerland), vol. 20, no. 3, pp. 4204-4224, 2015. 
[37] C. A. Gonçalves and R. C. C. Lelis, "Tannin content of the bark and wood of five Leguminosae species," Floresta e Ambiente, vol. 18, no. 1, pp. 1-8, 2011.

[38] A. Ohsaki, R. Yokoyama, H. Miyatake, and Y. Fukuyama, "Two diterpene rhamnosides, Mimosasides B and C, from Mimosa hostilis," Chemical and Pharmaceutical Bulletin, vol. 54, no. 12, pp. 1728-1729, 2006.

[39] I. A. d. Nascimento, R. Braz-Filho, M. G. d. Carvalho, L. Mathias, and F. d. A. Fonseca, "Flavonoides e outros compostos isolados de Mimosa artemisiana Heringer e Paula," Química Nova, vol. 35, no. 11, pp. 2159-2164, 2012.

[40] N. B. Monção, L. M. Costa, D. D. Arcanjo et al., "Chemical constituents and toxicological studies of leaves from Mimosa caesalpiniifolia Benth., a Brazilian honey plant," Pharmacognosy Magazine, vol. 10, no. 3, pp. S456-S462, 2014.

[41] E. Pisha, H. Chai, I.-S. Lee et al., "Discovery of betulinic acid as a selective inhibitor of human melanoma that functions by induction of apoptosis," Nature Medicine, vol. 1, no. 10, pp. 1046-1051, 1995.

[42] S. Fulda, C. Friesen, M. Los et al., "Betulin acid triggers CD95 (APO-1/Fas) and p53-independent apoptosis via activation of caspases in neuroectodermal tumors," Cancer Research, vol. 57, no. 21, pp. 4956-4964, 1997.

[43] S. Fulda, I. Jeremias, H. H. Steiner, T. Pietsch, and K.-M. Debatin, "Betulinic acid: a new cytotoxic agent against malignant brain-tumor cells," International Journal of Cancer, vol. 82, no. 3, pp. 435-441, 1999.

[44] S. Fulda and K.-M. Debatin, "Betulinic acid induces apoptosis through a direct effect on mitochondria in neuroectodermal tumors," Medical and Pediatric Oncology, vol. 35, no. 6, pp. 616-618, 2000.

[45] S. Fulda and K.-M. Debatin, "Sensitization for anticancer drug-induced apoptosis by betulinic acid," Neoplasia, vol. 7, no. 2, pp. 162-170, 2005.

[46] V. Zuco, R. Supino, S. C. Righetti et al., "Selective cytotoxicity of betulinic acid on tumor cell lines, but not on normal cells," Cancer Letters, vol. 175, no. 1, pp. 17-25, 2002.

[47] D. Thurnher, D. Turhani, M. Pelzmann et al., "Betulinic acid: a new cytotoxic compound against malignant head and neck cancer cells," Head \& Neck, vol. 25, no. 9, pp. 732-740, 2003.

[48] H. Ehrhardt, S. Fulda, M. Führer, K. M. Debatin, and I. Jeremias, "Betulinic acid-induced apoptosis in leukemia cells," Leukemia, vol. 18, no. 8, pp. 1406-1412, 2004.

[49] S. Fulda, "Betulinic acid for cancer treatment and prevention," International Journal of Molecular Sciences, vol. 9, no. 6, pp. 1096-1107, 2008.

[50] J. B. Foo, L. Saiful Yazan, Y. S. Tor et al., "Induction of cell cycle arrest and apoptosis by betulinic acid-rich fraction from Dillenia suffruticosa root in MCF-7 cells involved p53/p21 and mitochondrial signalling pathway," Journal of Ethnopharmacology, vol. 166, pp. 270-278, 2015.

[51] M. Fenech, "The in vitro micronucleus technique," Mutation Research, vol. 455, no. 1-2, pp. 81-95, 2000.

[52] M. Fenech, "Cytokinesis-block micronucleus assay evolves into a "cytome" assay of chromosomal instability, mitotic dysfunction and cell death," Mutation Research, vol. 600, no. 1-2, pp. 58-66, 2006.

[53] A. N. C. Sortibrán, M. G. O. Téllez, and R. R. Rodríguez-Arnaiz, "Gentotoxic profile of inhibitors of topoisomerase I (camptothecin) and II (etoposide) in a mitotic recombination and sex-chromosome loss somatic eye assay of Drosophila melanogaster," Mutation Research, vol. 604, no. 1-2, pp. 83-90, 2006.

[54] P. Noordhuis, U. Holwerda, C. L. Van Der Wilt et al., "5fluorouracil incorporation into RNA and DNA in relation to thymidylate synthase inhibition of human colorectal cancers," Annals of Oncology, vol. 15, no. 7, pp. 1025-1032, 2004.

[55] G. M. Zúñiga-González, O. Torres-Bugarín, A. L. ZamoraPerez et al., "Induction of micronucleated erythrocytes in mouse peripheral blood after cutaneous application of 5fluorouracil," Archives of Medical Research, vol. 34, no. 2, pp. 141-144, 2003.

[56] M. Misik, C. Pichler, B. Rainer, M. Filipic, A. Nersesyan, and S. Knasmueller, "Acute toxic and genotoxic activities of widely used cytostatic drugs in higher plants: possible impact on the environment," Environmental Research, vol. 135, pp. 196-203, 2014.

[57] A. I. Minchinton and I. F. Tannock, "Drug penetration in solid tumours," Nature Reviews Cancer, vol. 6, no. 8, pp. 583-592, 2006.

[58] N. Muhamad and K. Na-Bangchang, "Metabolite profiling in anticancer drug development: a systematic review," Drug Design, Development and Therapy, vol. 14, pp. 1401-1444, 2020.

[59] A. S. Bass, M. E. Cartwright, C. Mahon et al., "Exploratory drug safety: a discovery strategy to reduce attrition in development," Journal of Pharmacological and Toxicological Methods, vol. 60, no. 1, pp. 69-78, 2009.

[60] D. Williams, N. Kitteringham, D. Naisbitt, M. Pirmohamed, D. Smith, and B. Park, "Are chemically reactive metabolites responsible for adverse reactions to drugs?" Current Drug Metabolism, vol. 3, no. 4, pp. 351-366, 2002.

[61] P. M. P. Ferreira, D. B. Santos, and J. D. N. Silva, "Toxicological findings about an anticancer fraction with casearins described by traditional and alternative techniques as support to the Brazilian Unified Health System (SUS)," Journal of Ethnopharmacology, vol. 241, Article ID 112004, 2019.

[62] L. Hou, C. Fan, C. Liu, Q. Qu, C. Wang, and Y. Shi, "Evaluation of repeated exposure systemic toxicity test of PVC with new plasticizer on rats via dual parenteral routes," Regenerative Biomaterials, vol. 5, no. 1, pp. 9-14, 2018.

[63] B. L. Rapoport, "Delayed chemotherapy-induced nausea and vomiting: pathogenesis, incidence, and current management," Frontiers in Pharmacology, vol. 8, pp. 1-10, 2017.

[64] G. C. G. Militão, I. N. Dantas, P. M. P. Ferreira et al., "In vitro and in vivo anticancer properties of cucurbitacin isolated from Cayaponia racemosa," Pharmaceutical Biology, vol. 50, no. 12, pp. 1479-1487, 2012.

[65] E. G. Giannini, R. Testa, and V. Savarino, "Liver enzyme alteration: a guide for clinicians," Canadian Medical Association Journal, vol. 172, no. 3, pp. 367-379, 2005.

[66] S. K. Ramaiah, "A toxicologist guide to the diagnostic interpretation of hepatic biochemical parameters," Food and Chemical Toxicology, vol. 45, no. 9, pp. 1551-1557, 2007.

[67] R. M. Trüeb, "Chemotherapy-induced alopecia," Current Opinion in Supportive and Palliative Care, vol. 4, no. 4, pp. 281-284, 2010.

[68] K. Nurgali, R. T. Jagoe, and R. Abalo, "Editorial: adverse effects of cancer chemotherapy: anything new to improve tolerance and reduce sequelae?" Frontiers in Pharmacology, vol. 9, pp. 245-247, 2018.

[69] J. D. Sara, J. Kaur, R. Khodadadi et al., "5-fluorouracil and cardiotoxicity: a review," Therapeutic Advances in Medical Oncology, vol. 10, pp. 1758835918780140-18, 2018. 